\author{
Iwona Lorenc \\ - https://orcid.org/0000-0003-3364-3953 \\ Institute of Philosophy, University of Warsaw \\ lorenc@cyberia.pl
}

\title{
TOWARDS A NEW PHILOSOPHICAL FUNCTIONALISATION OF THE CONCEPT OF ART
}

\begin{abstract}
I distinguish two ways of functionalising the concept of art in modern thinking: a metacritical way and a way where it is treated as exemplary experience. In both cases, the concept of art is diffused in the aesthetic, and the stake in the game of its new functionalisation in the field of contemporary humanities is updating of the question of autonomy of art. My claim is that in view of the contemporary challenges posed by the processes of fictionalisation of reality, tendencies towards autonomisation of art and transgression of its boundaries are inseparable from each other. Phenomenological and hermeneutic researches provide a good account of this situation.
\end{abstract}

Keywords: research turns in humanities, aesthetics as metacriticism, art as examplary experience, autonomy of art, artistic appearance, fictionalisation of reality

Contemporary, philosophical thinking about art must face the challenge posed by the deep transformation that is taking place in philosophy itself - the change in its perspectives and instruments. It also has to meet the challenge presented by artistic practice that constantly pushes the boundaries of art, its place within broadly understood social, cultural, and economic practices, as well as the changing character of sensibility of contemporary audiences.

On one hand, today's high art is doing fairly well: museums, philharmonics, opera theatres are far from empty (although, we are more or less commonly aware of the functional transformations in the field of social, political or market contexts of these institutions). On the other hand, however, the substitution of stable structures of experience with the experience of happening and 
disappearing, medialisation or broadly understood aesthetisation of our world manifest themselves, among others, in the form of mutual permeation of high and popular art, and everyday experiences. We listen to classical music in the car, contemporary opera or film blend different genres, and classical pieces are mixed with pop music.

No wonder that traditional aesthetics, borne out of the spirit of Baumgarten and Kant, the philosophy of art that draws on the philosophy that systemically legitimizes traditional values (such as beauty, the sublime, pathos, the tragic, etc.) becomes subject to renewed, sometimes skeptical, methodological, but also interdisciplinary reflection. More and more often, it concerns the relation between the transformations taking place in contemporary art and the processes of phenomenalisation resp. fictionalisation of contemporary reality (following in the footsteps of Nietzche, Vattimo, on one hand, and Baudrillard, Debord, on the other). In consequence of this reflection, if we do not wish to deprive aesthetics of its broad, philosophical breath, it has to rethink its metaphysical lineage in view of the transformation taking place in philosophy itself as well as revise the concepts that it operates with. Especially, given that we still have trouble applying the instruments of traditional aesthetics that is tied to metaphysics to contemporary reality - to the requirements of contemporary humanities and, at the same time, to the requirements of changing art.

In humanities, philosophy, and aesthetics, traditional terms, such as art, are still valid and we continue to go back to the old solutions that have been well established in the history of philosophy. At the same time, however, the philosophical crisis of traditional metaphysics and the break from systemic practice of philosophy deprives aesthetics of its safe place among the faculties that could comprise a hierarchical and structured whole.

I do not believe that the awareness of such a state of affairs should lead us to completely give into the ephemeral fascinations with absolutised new centers that are characteristic of contemporary humanities, and which are supposed to organise the field of research on art, and make us abandon the philosophical ground of reflection as "essential thinking" (to use Heidegger's language) for the sake of such fascinations.

The term used by contemporary humanities is "turn". It seems that it replaces the former divisions of experiences based on the assumption of independence and separation of legitimizations of particular fields. Authors who wrote about this phenomenon, such as Medick-Bachmann ${ }^{1}$ or the authors of the collective work entitled Zwroty badawcze w humanistyce. Konteksty poznawcze, kulturowe

1 Cf. D. Medick-Bahmann, Cultural Turns. New Orientations in the Study of Culture. (trans. by Adam Blauhut). De Gruyter, Belin/Boston 2016. 
i spoteczno-instytucjonalne $e^{2}$ enumerate the following turns: interpretative, reflexive, performative, memory, spatial, somatic, affective, and iconic. The list remains open, however, let us add: aesthetic (e.g. in phenomenology), posthumanist, linguistic, narrative, and textual turn. The multitude of universalising claims, new perspectives that come to be called "turns" comprise an open, dynamic, and labile picture of contemporary humanities, whose more or less ephemeral centers are trying to subsume as broad thematic field as possible, and at the same time - in response to the proposed perspective - provoke the generation of ever new centers. It is no longer a picture of a calm and static coexistence that could be led (the question is if they ever did?) by separate domains of experience, which had their own legitimization, deriving their autonomy from the old, Kantian division into faculties.

The research conducted by contemporary, "de-expertised" humanities is especially sensitive to diverse contexts and the interplay of competing points of view, which often change along with the changes in their subject matter. Let us give some examples: we may invoke, for example, the research of such culturally-oriented historians of art and researches of visual culture as Mieke Bal, Timothy James Clark, James Elkins, and in aesthetics, for instance, Jacques Rancičr. One of the concepts that has been enjoying considerable popularity in the recent years is plasticity of ideas (Catherine Malabou). It is a response to the challenge posed by the late modern changes that led to the blurring of boundaries between identities. These changes preclude conceptual stabilisation of humanitites, which usually construct a particular picture of the world based on concepts that have stable meanings. The concept of plasticity which, in Malabou's opinion, reflects this situation of destabilisation of meanings refers to a model of art that has gained the ability to emerge forms better than any other field of human activity. They destabilise old meanings, but at the same time ensure their continuity; break down established identities and transpose the process of understanding into a space of new references and configurations.

It is worth to reflect on the status of art and the aesthetic within the confines of metatheoretical reflection. In this perspective, art and the aesthetics are placed at the base of reflection on the methodological status of contemporary humanist thought.

This move replicates the blueprint from 19th and 20th century philosophy, whose creation and consolidation we owe in part to Immanuel Kant. Its essential feature is the functionalisation of the concept of art and the potential of its meaning in the field of philosophical tasks, in order to solve the difficul-

2 Zwroty badawcze w humanistyce. Konteksty poznawcze, kulturowe i spoteczno-instytucjonalne, eds. J. Kowalewski, W. Piasek, Uniwersytet Warmińsko-Mazurski, Olsztyn 2010. 
ties which are impossible to deal with using the old philosophical means. Let us recall here, for example, using art in the function of a model of a desired totality (Hegel, Schiller, Lukacs); or Schelling, Nietzsche, and Adorno, who use art in the function of a tool that serves to transgress the order of reason and cognition.

Let us stop at Schelling, for instance. In his transcendental philosophy, art takes over the tasks of philosophy which can no longer fulfil it. This is possible thanks to the fact that art operates with sensible means of expression and gives a concrete character to the originary, absolute unity of the real and the ideal.

In the case of Marquard or Welsch, who use the motif of Kant's Critique of Pure Reason, the model of philosophising and practicing humanities is not only art, but also the broader field of the aesthetic. It is also nothing new, as Marquard notes. In his opinion (and he is not alone in it), the idea of compensating for the weakened functions of reason appeared as early as 18th century, when aesthetics was a manifestation of a search for compensation for the evil prevailing in the world. After Kant - says Wolfgang Welsch echoing Marquard - aesthetics will take the place of the ruling fundamental philosophy, a specifically understood "first philosophy".

One characteristic feature of the above mentioned tendencies is gearing towards metacritical reflection: reflection which unfolds on a "meta" level greatly facilitates "trans-" and "supra-" facultative excursions, which are often made in place of solid, concrete research on art. The limits of identity of art's subject matter are being blurred, wihile some of its features are being universalised to the rank of a paradigm of a new way of thinking in humanities - one that has been "expunged" of historical, social, and cultural contexts.

Metacritical functionalisation of art in philosophy and, more broadly, in human sciences is certainly contributing to the blurring of its subject matter boundaries. Simultaneously, the same effects are brought about by the growing popularity of the category of experience.

For some time now, the concept of aesthetic experience has been enjoying considerable popularity in aesthetics. The fact may be treated as a symptom of a growing interest in the category of experience in philosophy (as a category that allows to go beyond the old metaphysical schemes). A convincing account of the phenomenon is presented by Marting Jay in Songs of Experience, where he points to a new perspective of accounting for experience in contemporary philosophy and the functioning of the concept in various discourses, for example, in aesthetic discourse. He reconstructs the understanding of aesthetic experience from Kant to Dewey as a history of a struggle with aesthetic autonomism.

Another author, Arnold Berleant, highlights in turn that by isolating the separate fields of knowledge, morality, and aesthetic judgment, Kant stimu- 
lated and validated processes that lead to the separation of disciplines and theoretically "enhanced" economic, political, and legal practices related to this division. For instance, we live in a world in which scientific, technological, and economic processes have no moral standards. Consequently, there is a need for philosophy that - following the path set out by schools of thinking of the previous century (phenomenology, Heidegger, Sartre, Merleau-Ponty, hermeneutics, deconstructions, postmodernism, etc.) - would be constituted above such divisions. In addition, Berleant shows that the Kantian formula of disinterestedness does not yield good results in the evaluation of traditional and contemporary art. In its place, we need an aesthetics of engagement, an aesthetics of integration of experience in the field of perception. He sketches out a picture and character of aesthetic engagement in various fields: theory, the sphere of everyday practice, broadly understood creativity, art. He proposes various ways of transgressing traditional aesthetics, places special emphasis on incorporating the problematic of the body and sensibility into aesthetic research, and expands aesthetics with the already familiar fields of action and practice. This, let us add, would include the growing interest in performative practices that has been exhibited by philosophers, aestheticians, and theoreticians of culture.

In both above mentioned tendencies, which are strongly rooted in the modern reflection on art - the metacritical functionalisation of the concept and its treatment as exemplary experience, the concept of art is diffused in the aesthetic, and the stake in the game of its new functionalisation in the field of contemporary humanities is upholding the autonomous position of both concepts. I do not wish to be misunderstood: it is not about going back to the rigid, post-Kantian division into faculties. This is impossible. Rather, it is about not throwing the baby out with the bathwater in the fervor of the struggle against the Kantian inheritance, i.e. the struggle with autonomisation of the aesthetic and the rigid conceptual framework of art inherited after metaphysical tradition, in order not to lose sight of the need to reflect on art of essential nature, for example, one enabled by the hermeneutic and phenomenological perspective. It is obvious to me that the above-mentioned turns towards casting art in a metacritical function or a function of exemplary experience play a positive role, given that they expand the thematic and methodological field of philosophy of art and enrich our perspective of philosophical research on art. They should not, however, make us veer off track which philosophy of art followed for centuries as part of philosophy. They should not distance us from questions of essential and general nature. In view of the needs of contemporary times, it is worth to return to the important, question of foundations and limits of autonomy of art prepared by ancient, medieval, and early modern aesthetics.

In the present argument, I will point out a vital, emerging, and upheld line of tensions. It concerns both philosophy of art and aesthetics, as well as its sub- 
ject matter - art, and more broadly - the aesthetic. These are the tensions borne in the processes of the blurring of boundaries of these fields, on one hand, and of fostering the tendencies towards their autonomisation, on the other.

It is no accident that the transfacultative character of Critique of Pure Reason has been so often explored by late modern and postmodern critiques of the sharp divisions between faculties that characterise modern rationality. Critique of Pure Reasons manifests Kant's strive to bring the spheres of the functioning of reason into unity, in order to retrieve this unity in spite of and above the antinomies of the human world. Considering the aesthetic sphere as a field that possesses a potential for reconciliation, manifesting the originary unity of reason, inspired, as we know, the classical German philosophies of art, both in Schiller's and Hegel's versions. The motif of transfacultative meaning of the "third critique" taken up by the already mentioned critics of modernity such as Marquard, Derrida, Lyotard or Welsh meant a resignation from the longing for a unity of reason that is rooted in Enlightenment. However, the intention to assign aesthetics a mediating function does not mean a resignation from the ambition of replacing the old, metaphysical system of justifications with the aesthetic. In the modern and late modern interpretation of the said philosophical intention, which found its culmination not only in Romantic conceptions, but also in Nietzche, Heidegger or Adorno who struggle with the metaphysical parergon, the aesthetic gains a distinguished position (of a mediating, distancing, negating, originary sphere). This happens thanks to its autonomous character, thanks to the strangeness, heterogeneity of the aesthetic vis-à-vis the dichotomised world - totally reified, estranged, obscured by world picture, etc.

In short: more and more often, it is perceived that today's reality is permeated by aesthetic experience; paradoxically, due to the very fact that it has been defined as separate from reality thanks to aesthetic autonomy.

Aesthetic autonomism is the vehicle of its own destruction as it becomes an important ally in the anti-metaphysical battle initiated by late modernity. That is why, in the case of Nietzsche, Heidegger, and their successors, as well as many thinkers discussed in this essay the aesthetic plays a double role - the role of an autonomous sphere that breaks away from the old forms of organisation of the world and a sphere that permeates the experience of late modern reality, existing only as inextricably linked with the ways its manifests, and resisting encapsulation in a formula of a separate order detached from the experience. The processes that led to the separation of art from other fields of cultural experience as well as the ones that blur the separation and destabilise the formerly accepted formulas of art are mutually complementary.

When it comes to philosophies that proclaim the inseparability of both processes, invaluable is the contribution of contemporary phenomenology, 
which has been creatively providing many philosophical arguments in favour of this inseparability - often in opposition to its doctrinal Husserlian version, but hand in hand with hermeneutics. The concept of art does not lose its universal, culturally inherited validity, but becomes dynamised and open to new complementations. In hermeneutic-phenomenological research practices, it demands a tailor-made interpretation of individual, idiomatic artistic events.

Hermeneutic-phenomenological interpretation of art treats it as an exemplary (and therefore, also individual and general) experience of the world, as a never-ending process/event of self-manifestation of the phenomenon of the world. What does this special adherence of the above-mentioned task to the phenomenological-hermeneutic method consist in?

Heidegger, similarly to some other contemporary phenomenologists (I will not cite their long list here for the sake of clarity of argumentation), but above all Mealeau-Ponty and Dufrenne, try to give an account of the reciprocity of the shaping of the "I" and the "world", which is related in an vital way to the intention to break away from the ontotheological tradition (in total, as in the case of Heidegger or from some of its solutions, as in the case of Merleau-Ponty and Dufrenne).

In this perspective, the way I perceive the world is not generated by it in advance, and neither is it created, normalized, and sanctioned by the subject (either absolute or transcendental) that would be situated outside the world, in an ontological or cognitive sense. Rather, there is an essential co-dependence of the "I" and "the world", my being in it and shaping of the I by it. Phenomenologico-hermeneutic concept of art is at the center of reflection on thus understood experience. At the same time, which needs to be highlighted, it allows to realize and reflect upon the progressive process of art "catching up" to the modern experience of the world. On one hand, reflection on art, especially contemporary art, allows to question the traditional division into appearance and reality; on the other hand - it allows to develop a research sensibility that is sensitive to the processes of fictionalisation of reality.

Increasingly often, the artists and philosophers who wish to stay faithful to the mimetic and metaphysical tradition find themselves at a loss for "language" that would be able to reflect the widening gap between the processes of social, political, cultural fictionalisation of reality and the experiences of helplessness in the face of new dangers accompanied by the fictionalisation.

Contemporary art possesses, to a higher degree than other modern practices, an enormous, inherent, autoreflexive potential. It points to its own representational character, and by the virtue of this reflexive auto-demonstrativity - reveals the representational character of the cultural, social, and political environment of the modern man. 
Modern experience is characterized by a gap or a shifting apart of fictonalised reality and realised fiction: "in the opposition between fantasy and reality, the Real is on the side of fantasy" 3 notes Žižek, inspired by Marks and Lacan. We experience the spectral Real as reality, and forgetting the factical dimension of life is inscribed into our experience. The point is not to expose the spectrality (falsity) of truths that guide us, but to come to terms with the constant presence of un-truth in what we accept as true. In this respect, Žižek follows Heidegger, rather than Nietzche. He justly highlights, after Heidegger, that the turn or aberration (i.e. the "seniority" of untruth over truth) has the character of "ontological madness", consists in the "'derangement' of man's position among beings (his self-centeredness)."

In view of the above conclusions, the fictionality of art becomes a philosophical topic that has to be considered anew. Contemporary aesthetic experience, precisely due to its fictional character, brings us closer to the real dimension of social reality than philosophical or scientific cognitive operations, and certainly more than everyday experience. Because of it, we find ourselves beyond the opposition between fantasy/fiction and reality, and consequently, we also are beyond the division of experiences founded on this opposition.

On one hand, at present, we do not question the negative consequences of the detachment of aesthetic conceptions of art and aesthetic experience from other spheres of cultural experiences, the introduction of the aesthetic into an area that is disengaged from social practice, everyday life, human action, social norms and judgment, institutional conditions, etc., and finally, their disengagement from the teleology of human life and its existential dimensions. On the other hand, no one negates the constructive contribution of the aesthetic, even if it is articulated in the forms of most highly alienated aestheticism, in the development of broadly understood spiritual values or in the subjective and cultural process of self-understanding and self-education. Regardless if we are assessing aesthetic autonomisation critically or positively, we are still most often guided in these practices by post-Enlightenment, regulative idea of human vocation, however we understand it, which was elicited by Kant, and modified for contemporary needs.

Generally speaking, after Nietzsche, Heidegger, but also after Rorty, Dewey or Shusterman, contemporary varieties of phenomenology (especially pheno-

3 S. Žižek, The Fragile Absolute: Or, Why Is the Christian Legacy Worth Fighting For? New York: Verso, 2000, p. 67; Here, we see the introduction of the Lacanian distinction into the Real and reality: "'reality' is the social reality of the actual people involved in interaction, and in the productive process; while the Real is the inexorable 'abstract' spectral logic of Capital which determines what goes on in social reality" (Ibid., p. 15).

4

S. Žižek, ibid., p. 81. 
menology of embodiment or hermeneutics), aesthetic experience is an experience of self-understanding of the subject and good life and it cannot be juxtaposed to action, practice, engagement. In this way, today's aesthetics implements the Kantian idea of transfacultativity. It does so by blurring and transgressing the autonomy of the aesthetic, and this concerns both the new formulas of aesthetics, as well as a large part of artistic practices and their corresponding concepts, with the concept of art at the forefront. Aesthetics is becoming more and more sensitive to the interplay of what is autonomous and non-autonomous in art created by contemporary artists.

transl. Karolina Chodzińska-Bosak

\section{BIBLIOGRAPHY:}

Medick-Bahmann Doris (2016), Cultural Turns. New Orientations in the Study of Culture, transl. by Adam Blauhut, Berlin/Boston: De Gruyter.

Zwroty badawcze w humanistyce. Konteksty poznawcze, kulturowe i spoteczno-instytucjonalne (2010) eds. J. Kowalewski, W. Piasek, Olsztyn: Uniwersytet Warmińsko-Mazurski.

Žižek Slavoy, The Fragile Absolute: Or, Why Is the Christian Legacy Worth Fighting For? New York: Verso, 2000.

\section{KU NOWEJ FILOZOFICZNEJ FUNKCJONALIZACJI POJĘCIA SZTUKI (streszczenie)}

Wyróżniam w nowoczesnym namyśle nad sztuką dwa sposoby funkcjonalizowania tego pojęcia: sposób metakrytyczny i sposób traktowania jej jako egzemplarycznego doświadczenia. W obu przypadkach pojęcie sztuki rozmywa się w tym, co estetyczne, a stawką w grze o jego nową funkcjonalizację w polu współczesnej humanistyki jest uaktualnienie pytania o autonomię sztuki. Twierdzę, że w świetle współczesnych wyzwań płynących ze strony procesów fikcjonalizacji rzeczywistości, tendencje do autonomizacji sztuki i przekraczania jej granic są nierozdzielne. Dobrze zdają z tego sprawę badacze o orientacji fenomenologiczno-hermeneutycznej.

Słowa klucze: Zwroty badawcze w humanistyce, estetyka jako metakrytyka, sztuka jako egzemplaryczne doświadczenie, autonomia sztuki, pozór artystyczny, fikcjonalizacja rzeczywistości 
Iwona Lorenc - Professor of Philosophy at the University of Warsaw, her publications include: Why Art? Introduction to the Philosophy of Art (1989), Logos and the Myth of Aestheticism (1993), Consciousness and Image. Studies on the Philosophy of Presentation (2003), French Phenomenology (coauthor, 2006), Around French Phenomenology (coauthor, 2007), Minima Aesthetica. Essays on the Aesthetics of Late Modernity (2010), The Spaces of Late Modernity (coautor, 2011), The Aesthetic Problems of Late Modernity (2014). Author of dozens of works on aesthetics and contemporary philosophy, especially French philosophy and phenomenology. 